\title{
Ischaemic stroke caused by spontaneous unilateral carotid artery dissection in patient with connective tissue disorder
}

\author{
Udar niedokrwienny mózgu spowodowany samoistnym jednostronnym \\ rozwarstwieniem tętnicy szyjnej u pacjentki z chorobą tkanki łącznej
}

'Student Scientific Group at the Department of Neurology, Medical University of Bialystok, Białystok, Poland

${ }^{2}$ Department of Neurology, Medical University of Bialystok, Białystok, Poland

${ }^{3}$ Department of Radiology, Medical University of Bialystok, Bialystok, Poland

Correspondence:Weronika Pużyńska, Klinika Neurologii, ul. M. Skłodowskiej-Curie 24A, 15-276 Białystok, Poland, tel.: +4885746 83 26, fax: +48 857468608 , e-mail: wera9638@gmail.com

Abstract Background: Spontaneous cervical artery dissection is a major cause of ischaemic stroke in young patients. It is supposed that genetic variants associated with connective tissue disorders often lead to neurovascular complications, the management of which remains a challenge. Case presentation: A 30-year-old female was admitted to the Department of Neurology with an episode of visual disturbances, speech problems, and concomitant headache. Computed tomography angiography revealed left internal carotid artery dissection. Magnetic resonance of the brain showed cortical and subcortical acute ischaemic lesions in the left cerebral hemisphere. The patient was diagnosed with vascular Ehlers-Danlos syndrome based on the clinical course of the disease. Conservative treatment was administered with full neurological recovery. Conclusion: It is very important for clinicians to consider the coexistence of genetically determined connective tissue disorders in young patients who develop arterial dissections.

Keywords: ischaemic stroke, cervical artery dissection, Ehlers-Danlos syndrome

Streszczenie Wstęp: Samoistne rozwarstwienie tętnicy szyjnej jest istotną przyczyną udaru niedokrwiennego mózgu u młodych pacjentów. Przypuszcza się, że warianty genetyczne związane z chorobami tkanki łącznej często prowadzą do powikłań naczyniowych, których leczenie nadal pozostaje wyzwaniem. Prezentacja przypadku: 30-letnia pacjentka została przyjęta do Kliniki Neurologii z objawami zaburzeń widzenia, problemami z mową i towarzyszącym bólem głowy. W angiografii tomografii komputerowej naczyń domózgowych stwierdzono rozwarstwienie lewej tętnicy szyjnej wewnętrznej. W rezonansie magnetycznym mózgu wykazano ogniska niedokrwienne zlokalizowane korowo i podkorowo w lewej półkuli mózgu. Prezentowane przez pacjentkę objawy kliniczne pozwoliły na ustalenie rozpoznania naczyniowego podtypu zespołu Ehlersa-Danlosa. Zastosowano leczenie zachowawcze, które przyniosło pełną poprawę stanu neurologicznego. Wnioski: Istotne dla lekarzy klinicystów jest rozważenie współistnienia genetycznie uwarunkowanych zaburzeń tkanki łącznej u młodych pacjentów, u których doszło do samoistnego rozwarstwienia tętnicy szyjnej.

Słowa kluczowe: udar niedokrwienny mózgu, rozwarstwienie tętnicy szyjnej, zespół Ehlersa-Danlosa. 


\section{INTRODUCTION}

$\mathrm{E}$ hlers-Danlos syndrome (EDS) is a group of genetically and clinically heterogeneous connective tissue disorders caused by the abnormal structure of connective tissue. According to The 2017 international classification of the Ehlers-Danlos syndromes, 13 subtypes were distinguished (Malfait et al., 2017). The dissections of medium and large arterial vessels (mostly the aorta and its branches) are usually present in patients with a vascular subtype (vEDS). This type of EDS is characterised by a specific facial appearance with thin, translucent skin, prone to bruising, and excessive mobility of small joints. The clinical image shows increased fragility of blood vessels, which leads to spontaneous dissections, rupture of their walls, often without prior vasodilation, and aneurysm formation. Arterial dissections may occur spontaneously, but in most cases they are triggered by stress and physical exertion with sudden onset and high intensity (Byers et al., 2017). Vasa vasorum rupture, caused by vascular fragility in EDS patients, could be a significant factor in carotid dissection, in addition to other dissection mechanisms. Another significant cause of carotid dissection is the coexistence of Eagle's syndrome (a rare condition characterised by a set of symptoms associated with an elongated styloid process) and vEDS (Ikenouchi et al., 2020). Carotid-cavernous fistula is the most common neurovascular complication in the vEDS subtype, while the second most expected neurovascular lesions are aneurysms (Olubajo et al., 2020). In the medical literature, strokes in patients with EDS are casuistic, so it is very difficult to find accurate data describing the proportion of stroke cases in the population of EDS patients (Ballabio et al., 2007).

Genetically determined connective tissue disorders may lead to neurovascular complications such as ischemic stroke due to cerebral artery dissection, the management of which remains a challenge. We present the case of a 30 -year-old woman with neurological signs secondary to carotid artery dissection in whom the clinical diagnosis of vEDS was established.

\section{CASE REPORT}

A 30-year-old female was admitted to the Department of Neurology, Medical University of Bialystok, with a transient (lasting 2 hours) sudden episode of visual disturbances and speech problems with a concomitant headache. She had a history of two caesarean sections due to premature rupture of the foetal bladder (in 2015 and 2019), spontaneous pneumothorax and right lung emphysema in 2011, and spontaneous colon perforation in 2015. On physical examination, she presented features typical of EDS: thin nose and lips, large eyes, joint hypermobility, and bruises. The results of laboratory tests and computed tomography (CT) of the brain were normal. CT angiography (CTA) of the head and neck revealed dilatation of the vessel wall and thrombosed false lumen with a severely narrowed lumen in the cervical and intracranial (petrous and cavernous)

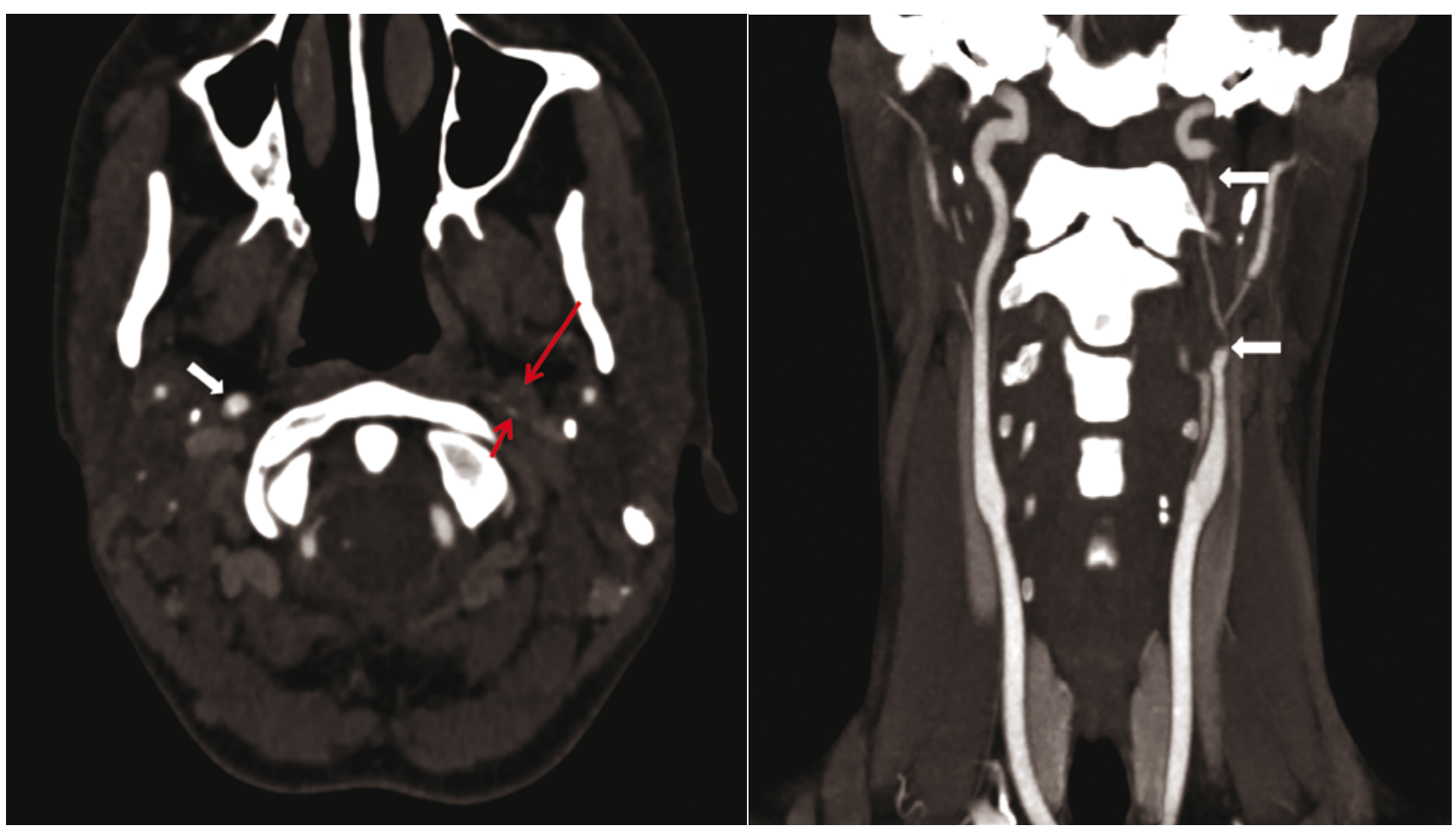

Fig. 1. A. Axial cervical CT angiography showing severely narrowed lumen of left ICA (short red arrow). Increased arterial diameter of the left ICA is due to eccentric intramural haematoma (long red arrow) in the distal portion of the cervical segment of left ICA. Normal right ICA lumen (thick white arrow). B. CT angiography, coronal maximum intensity projection reconstruction shows long tapered stenosis (arrow) of the left ICA with abnormal vessel contour - string sign 




Fig. 2. MRI of the brain performed following stroke symptoms. Cortical and subcortical FLAIR hyperintensity areas (A), adjacent restricted diffusion on DWI $(\boldsymbol{B})$ and ADC mapping $(\boldsymbol{C})$ in the left parietal lobe. D. Axial FLAIR image demonstrates dissection of the petrous segment of the left ICA with narrowing of the dark signal of the lumen (thin red arrow) surrounded by hyperintense rim compatible with intramular haematoma (thick white arrow)

segments of the left internal carotid artery (ICA) (Fig. 1 A, B). On the second day of hospitalisation, the patient's neurological condition worsened, and she presented right-sided hemianopsia, motor aphasia, and neck pain (National Institutes of Health Stroke Scale - score 3). Magnetic resonance imaging
(MRI) of the brain showed numerous cortical acute ischaemic lesions on the border of the left parietal and occipital lobes (Fig. 2 A-C). MRI images also revealed dissection of the petrous segment of the left ICA with narrowing of the true lumen surrounded by intramural haematoma (Fig. 2 D). 




Fig. 3. Follow-up CT angiography - 8 months after dissection. Coronal and sagittal maximum intensity projections show vast improvement in vessel patency. Only a small focal bulge remained on the anterior outline of the artery wall (arrow)

The patient was diagnosed with vEDS based on the clinical course of disease and her past medical history. Conservative treatment was administered with full neurological recovery. The patient was recommended to take rosuvastatin $5 \mathrm{mg}$ daily and celiprolol $100 \mathrm{mg}$ daily on a permanent basis; she was also taking acetylsalicylic acid $75 \mathrm{mg}$ and clopidogrel $75 \mathrm{mg}$ daily for 6 months after artery dissection. The genetic evaluation is in progress (so far, no mutation in the FBN1 gene was detected). There have been no new vascular or visceral events during 8 months of follow-up (Fig. 3). Intracranial and extracranial CT revealed no further morphologic abnormalities.

\section{DISCUSSION}

EDS is a group of connective tissue disorders related to abnormal synthesis and structure of connective tissue, which are inherited in an autosomal recessive or autosomal dominant manner depending on the subtype of the syndrome. vEDS is a heterogeneous disorder caused by mutations in the COL3A1 gene which lead to the synthesis of an abnormal type III collagen protein; this subtype accounts for less than 5\% of all EDS cases (Byers et al., 2017; Eagleton, 2016). Life-threatening complications like hiatal hernias, organ rupture (most commonly gastrointestinal perforations), and rectal and uterine prolapse are frequently present in adult patients (Byers et al., 2017). A sudden onset of the carotid-cavernous fistulae, dissecting aneurysms or arterial dissections in apparently healthy young people should suggest vEDS (Henrard et al., 2019). The age of presentation of vascular events shows a large diversity, but in $80 \%$ of patients with vEDS the first event of vascular dissection occurred by the age of 40 , with the mean age of the first cerebrovascular complication being 28 years (North et al., 1995). In the presented case, the patient showed physical features typical of vEDS: joint hypermobility and easy skin bruising. 


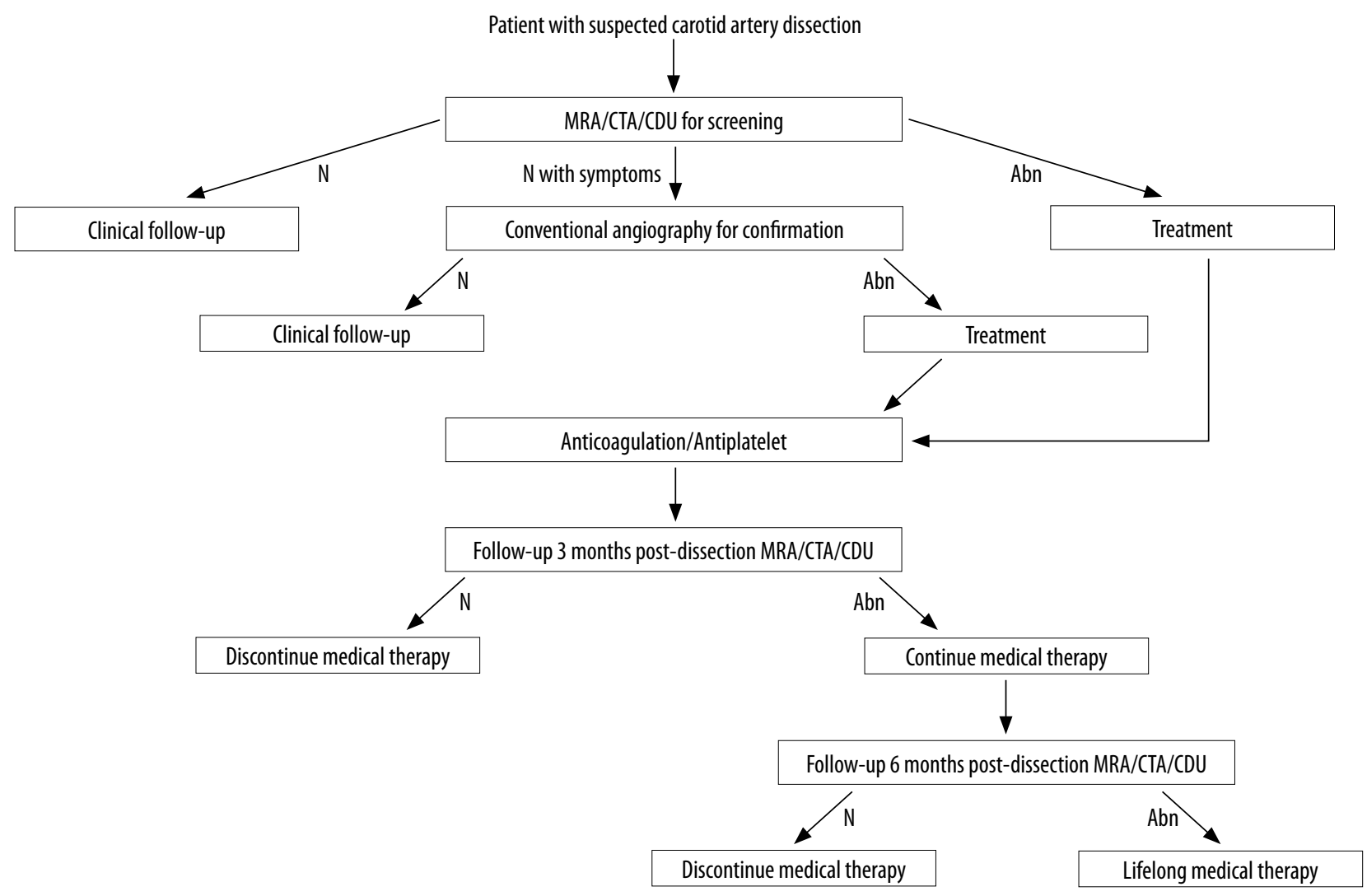

Fig. 4. Diagram showing a diagnostic and treatment pathway in the event of suspected vessel dissection. MRA - magnetic resonance angiography; CTA - computed tomography angiography; CDU - colour duplex ultrasound; $N$ - normal; $N$ with symptoms - normal with typical symptoms of carotid artery dissection; Abn - abnormal

The patient's past medical history revealed spontaneous perforation of the colon, spontaneous pneumothorax, and double rupture of the foetal bladder, which may indicate an abnormal structure of connective tissue. The patient's young age ( 30 years) at the moment of spontaneous arterial dissections is another typical feature of vEDS (Debette et al., 2014).

In cases involving spontaneous carotid artery dissection (sCAD) in young patients, all efforts should be made to diagnose the underlying condition. Genetic testing for the presence of the COL $3 A 1$ variants gene mutation should be done to confirm or rule out the presence of vEDS, which is the most common connective tissue disorder causing arterial dissection (Byers et al., 2017; Debette et al., 2014). If the tests do not confirm vEDS, genetic diagnostics should be continued towards other connective tissue diseases, such as classic EDS, hypermobile EDS, and osteogenesis imperfecta. Over the last years, a relationship between sCAD and fibromuscular dysplasia (FMD), an idiopathic, segmental, non-atherosclerotic and non-inflammatory arterial disease, has been suggested based on a number of epidemiologic observations (Bonacina et al., 2021; Henrard et al., 2019). Even though Marfan syndrome, Loeys-Dietz syndrome, FMD and Larsen syndrome are rarely observed congenital causes of arterial dissections, we should also remember about them (Debette et al., 2014). In our patient, no mutations in the FBN1 gene were found in the genetic evaluation, which ruled out Marfan syndrome. The patient is waiting for further genetic tests to be conducted.

Spontaneous arterial dissection in the course of vEDS usually affects only one blood vessel. However, it should be noted that dissections can occur in different arteries within a short time (Ohshima et al., 2019). A case of bilateral carotid dissection has also been described in a patient diagnosed with vEDS and Eagle's syndrome (Ikenouchi et al., 2020). This shows that patients with vEDS should be given special care after spontaneous arterial dissection to prevent future occurrences of the event.

The management of acute stroke due to SCAD in patients with vEDS is always challenging. In general, conservative treatment should be introduced (Fig. 4). Invasive procedures may only be used in life-threatening emergencies due to high complication rates (arterial re-dissection or stroke) and mortality. The diagnostic methods of vascular dissections in patients with EDS should be used in screening colour duplex ultrasound and CTA or MRI, which are helpful in assessing the recanalisation of the affected vessel (Benrashid and Ohman, 2020; Eagleton, 2016). CTA may show arterial stenosis, occlusion, or intramural haematoma, and 
the presence of an irregular pattern of the wall (local intimal flap) may also suggest the place of the dissection, which was observed in our patient. MRI is a sensitive method for imaging intramural haematoma. The highest sensitivity is demonstrated by transverse T1-weighted images with fat saturation, in which the intramural haematoma shows a high sickle-shaped signal. Despite reports of successful treatment of carotid dissections by embolisation in patients with vEDS, surgical procedures/endovascular treatment are generally not recommended due to the fragility of peripheral vessels (Henrard et al., 2019; Ohshima et al., 2019; Okada et al., 2014). Physicians should carefully weigh the risks and benefits of the intervention, as the incidence of endovascular complications. In our patient, endovascular treatment was not implemented.

In the absence of causative treatment options for vEDS, it is essential to provide patients with symptomatic and preventive treatment, and genetic counselling. Celiprolol (a third generation $\beta 1$-adrenoreceptor antagonist with primarily vasodilatory effects) is currently the treatment of choice in the pharmacological management of vEDS. In recent studies (Baderkhan et al., 2021), celiprolol treatment (at the recommended dose of $400 \mathrm{mg}$ daily) was shown to improve survival in patients with vEDS, However, there is still a scarcity of high-quality trials assessing the efficacy of celiprolol in the treatment of vEDS. The effectiveness of therapy with bisoprolol or losartan is not well studied, either (Benrashid and Ohman, 2020).

In the presented patient, conservative treatment including dual antiplatelet therapy, statin and celiprolol led to clinical improvement, and there was no need for endovascular intervention. CTA repeated 8 months after dissection showed the left ICA without stenosis. No new vascular or visceral events were observed.

Antithrombotic medication is frequently used to prevent new or recurrent ischaemic stroke symptoms caused by arterial dissection after the acute period of stroke. Antithrombotic treatment with either antiplatelet or anticoagulant therapy is generally recommended for individuals with acute ischaemic stroke or transient ischaemic attack (TIA) caused by extracranial carotid or vertebral artery dissection. The choice between antiplatelet and anticoagulant medication should be based on the treating physician's clinical experience as well as on shared decision-making that takes into account the patient's values and preferences, concomitant conditions, and drug tolerance (Liebeskind, 2021). It is very important for clinicians to consider the coexistence of genetically determined connective tissue disorders in patients who develop arterial dissection. A careful history (especially past medical and family history) and physical examination are critical to reveal information suggestive of a congenital connective tissue disease diagnosis which should be confirmed by genetic testing. The risk of recurrent arterial dissection and stroke is high in this group of patients.

\section{Conflict of interest}

The authors do not report any financial or personal connections with other persons or organizations which might negatively affect the contents of this publication and/or claim authorship rights to this publication.

\section{References}

Baderkhan H, Wanhainen A, Stenborg A et al.: Celiprolol treatment in patients with vascular Ehlers-Danlos syndrome. Eur J Vasc Endovasc Surg 2021; 61: 326-331.

Ballabio E, Bersano A, Bresolin N et al.: Monogenic vessel diseases related to ischemic stroke: a clinical approach. J Cereb Blood Flow Metab 2007; 27: 1649-1662.

Benrashid E, Ohman JW: Current management of the vascular subtype of Ehlers-Danlos syndrome. Curr Opin Cardiol 2020; 35: 603-609.

Bonacina S, Locatelli M, Mazzoleni V et al.: Spontaneous cervical artery dissection and fibromuscular dysplasia: epidemiologic and biologic evidence of a mutual relationship. Trends Cardiovasc Med 2021. DOI: 10.1016/j.tcm.2021.01.006.

Byers PH, Belmont J, Black J et al.: Diagnosis, natural history, and management in vascular Ehlers-Danlos syndrome. Am J Med Genet C Semin Med Genet 2017; 175: 40-47.

Debette S, Goeggel Simonetti B, Schilling S et al.; CADISP-plus consortium: Familial occurrence and heritable connective tissue disorders in cervical artery dissection. Neurology 2014; 83: 2023-2031.

Eagleton MJ: Arterial complications of vascular Ehlers-Danlos syndrome. J Vasc Surg 2016; 64: 1869-1880.

Henrard C, Belge H, Fastré S et al.: Cervical artery dissection: fibromuscular dysplasia versus vascular Ehlers-Danlos syndrome. Blood Press 2019; 28: 139-143.

Ikenouchi H, Takagi M, Nishimura A et al.: Bilateral carotid artery dissection due to Eagle syndrome in a patient with vascular EhlersDanlos syndrome: a case report. BMC Neurol 2020; 20: 285.

Liebeskind DS: Spontaneous cerebral and cervical artery dissection: treatment and prognosis. UpToDate 2021.

Malfait F, Francomano C, Byers P et al.: The 2017 international classification of the Ehlers-Danlos syndromes. Am J Med Genet C Semin Med Genet 2017; 175: 8-26.

North KN, Whiteman DA, Pepin MG et al.: Cerebrovascular complications in Ehlers-Danlos syndrome type IV. Ann Neurol 1995; 38: $960-964$.

Ohshima T, Miyachi S, Isaji T et al.: Bilateral vertebral artery dissection and unilateral carotid artery dissection in case of Ehlers-Danlos syndrome type IV. World Neurosurg 2019; 121: 83-87.

Okada T, Frank M, Pellerin O et al.: Embolization of life-threatening arterial rupture in patients with vascular Ehlers-Danlos syndrome. Cardiovasc Intervent Radiol 2014; 37: 77-84.

Olubajo F, Kaliaperumal C, Choudhari KA: Vascular Ehlers-Danlos syndrome: literature review and surgical management of intracranial vascular complications. Clin Neurol Neurosurg 2020; 193: 105775. 